\title{
G2/Mitotic-Specific Cyclin-B1
}

National Cancer Institute

\section{Source}

National Cancer Institute. G2/Mitotic-Specific Cyclin-B1. NCI Thesaurus. Code C17981.

G2/mitotic-specific cyclin-B1 (433 aa, $\sim 48 \mathrm{kDa}$ ) is encoded by the human CCNB1 gene.

This protein plays a role in mediating the progression of the cell cycle from $\mathrm{G} 2$ to mitosis. 